\title{
Pelatihan hygiene sanitasi dan poster berpengaruh terhadap pengetahuan, perilaku penjamah makanan, dan kelaikan hygiene sanitasi di instalasi gizi RSUP Sanglah Denpasar ${ }^{1}$
}

\author{
Ni Wayan Rapiasih², Yeni Prawiningdyah ${ }^{3}$, Lily Arsanti Lestari ${ }^{4}$
}

\begin{abstract}
Background:The problem of food hygiene sanitation in hospital is closely related to the incidence of nosocomial infection which is estimated to be high considering that the condition of hospitals and health in general is still relatively not very good. A way to transmit nosocomial infection is through food. Staff hygiene is a factor requiring attention in order that the product of nutrition installation is of quality and safe to consume.

Objective: To identify the effect of training and posting of food hygiene sanitation to knowledge, healthy behavior of food handlers in efforts to improve food safety and sanitation hygiene appropriateness.

Method: This was a time series quasi experiment with one group pre test and post test design. Samples consisted of 44 people of senior level education in charge of food service to patient in class I, II, and III. Every subject was given training using lecture, discussion and demonstration method for one day. Poster was posted a month after training. Data obtained consisted of sex, age, marital status, duration of occupation, place of work, knowledge, behavior, food safety in food serving utensil for inpatients and sanitation hygiene appropriateness. Assessment was made before, one month and two months after training. Data analysis used paired Sample t-test and chi-square.

Results: There was significant improvement in knowledge and healthy behavior before and after training plus poster showed with $p<0.001$. There was significant difference in sex and behavior before training with $p=0.045$ and a month after training with $p<0.001$. There was significant association between place of work and behavior a month after training with $p=0.021$. There was significant difference in total plate count one month and two months after training with $p=0.049$. In addition, there was an increased quality of sanitation hygiene appropriateness before and after training plus poster showed.

Conclusion: There was an increasing of knowledge, behavior of food handlers, sanitation hygiene appropriateness, before and after training plus poster. There was an improvement in quality food safety one and two months after training.
\end{abstract}

KEY WORDS Training, poster, knowledge, behavior, food safety, sanitation hygiene appropriateness

\section{PENDAHULUAN}

Masalah sanitasi makanan di rumah sakit sangat terkait dengan kejadian infeksi nosokomial yang diperkirakan cukup tinggi, mengingat keadaan rumah sakit dan sanitasi pada umumnya relatif belum begitu baik. Kurangnya sanitasi makanan dan personal hygiene dapat terjadi kontaminasi bakteri patogen yaitu Salmonella, Shigella, Vibrio cholera, Klebsiella, Campylobacter, E. coli, dan lain-lain, dapat menyebabkan penyakit demam tipoid, desentri, kolera, dan muntaber. Salah satu cara transmisi infeksi nosokomial yaitu melalui makanan, minuman dan air yang disajikan oleh rumah sakit untuk para pasien maupun petugas rumah sakit (1).

Sampel makanan rumah sakit mengandung total Coliform sebanyak 0,4 bakteri/gram makanan di Instalasi Gizi Rumah Sakit Hasan Sadikin Bandung, sedangkan makanan rumah sakit di dapur saji ruang rawat inap mengandung bakteri sebanyak 0,1-2,3 bakteri/gram makanan. Berdasarkan pemeriksaan usap tangan pada tenaga pengolah dan penyaji makanan terdapat bakteri sebanyak 0,008-0,002 E.coli per $\mathrm{cm}^{2}$ luas kedua permukaan tangan. Kontaminasi dapat terjadi oleh penjamah makanan, pengolah, dan penyaji makanan yang kurang memahami prinsip-prinsip sanitasi penyehatan makanan (2).
Pengelolaan makanan di rumah sakit mutlak diperlukan penerapan cara produksi pangan yang baik dan penerapan sanitasi pada kegiatan penyehatan makanan minuman di rumah sakit sehingga menghasilkan makanan yang bermutu dan aman untuk dikonsumsi sehingga kepercayaan pasien akan meningkat, dan juga pasien terhindar dari bahaya yang memperberat penyakitnya. Oleh karena itu kebersihan dan hygiene karyawan merupakan salah satu hal yang sangat penting yang harus diperhatikan industri pangan agar produk pangannya bermutu dan aman untuk dikonsumsi (3).

Faktor yang paling penting menentukan prevalensi penyakit bawaan makanan adalah kurangnya pengetahuan penjamah makanan dan ketidakpedulian terhadap

\footnotetext{
1 Dipresentasikan pada International Dietetic Update pada tanggal 15 17 Oktober 2009 di Yogyakarta kerjasama dengan Asosiasi Dietisien Indonesia, Jurnal Gizi Klinik Indonesia, dan Prodi Gizi Kesehatan FKUGM serta didanai oleh Pendidikan Tinggi Kementerian Pendidikan Nasional.

2 Instalasi Gizi RSUP Sanglah Denpasar, e-mail: asih_yan@yahoo. co.id

${ }^{3}$ Instalasi Gizi RSUP Dr. Sardjito, Jl. Kesehatan, Yogyakarta

${ }^{4}$ Program Gizi dan Kesehatan, Fakultas Kedokteran, UGM, JI. Farmako, Sekip Utara, Yogyakarta, e-mail: santi_wap@yahoo.com
} 
pengelolaan makanan yang aman. Pendekatan terpadu dalam pencegahan penyakit bawaan makanan adalah melalui pendidikan dan pelatihan bagi para penjamah makanan dalam hal keamanan makanan (4).

Laporan tahunan Instalasi Gizi menyebutkan Rumah Sakit Pusat Sanglah Denpasar adalah Rumah Sakit Tipe A Pendidikan dengan kapasitas tempat tidur sebanyak 687. Permintaan makanan pasien setiap harinya rata-rata sebanyak 550 orang, di antaranya yang berdiet khusus sebanyak 154 orang. Hasil pemeriksaan rectal swab pada tahun 2007 menunjukkan bahwa dari 100 orang yang diperiksa, 11 orang (11\%) di antaranya dinyatakan positif. Hal ini dapat disebabkan karena kurangnya pengetahuan sanitasi makanan dan hygiene perorangan (5).

Penelitian di RSUP Dr. Wahidin Sudirohusodo Makassar dapat meningkatkan pengetahuan, sikap, dan keterampilan dalam hal pengolahan bahan makanan. Di samping itu, pelatihan kuliner juga meningkatkan mutu makanan pasien pada semua aspek, namun aspek suhu sangat sulit dikendalikan sehingga masih dalam kategori kurang (6).

Sedangkan penelitian di RS Jantung Harapan Kita Jakarta menunjukkan bahwa sikap dan keterampilan penjamah makanan yang diberi pelatihan keamanan pangan mengalami peningkatan yang signifikan pada periode sebelum hingga 1 bulan dan 2 bulan setelah pelatihan, tetapi mengalami penurunan yang cukup signifikan pada periode 1 bulan hingga 2 bulan setelah pelatihan (7).

Terkait dengan hal tersebut di atas, maka diperlukan sumber daya manusia yang berkualitas, terampil, dan sehat untuk menghasilkan makanan yang berkualitas. Untuk mewujudkan hal tersebut, maka perlu adanya pelatihan hygiene sanitasi makanan, mengingat pelatihan hygiene sanitasi makanan belum pernah dilakukan pada penjamah makanan di RSUP Sanglah Denpasar. Berdasarkan Keputusan Menteri Kesehatan (Kepmenkes) Nomor 715/ Menkes/ SK/V/2003 bahwa penjamah makanan wajib mendapatkan pelatihan hygiene sanitasi dan memiliki sertifikat kursus penjamah makanan (8). Selain pelatihan juga dilakukan pemasangan poster yang berisi beberapa petunjuk kegiatan hygiene sanitasi, dengan tujuan untuk dapat mempertahankan atau meningkatkan pengetahuan dan perilaku sehat. Hal tersebut yang mendorong peneliti untuk melakukan penelitian tentang pelatihan hygiene sanitasi.

\section{BAHAN DAN METODE}

\section{Karakteristik subjek dan sampel penelitian}

Penelitian dilakukan di RSUP Sanglah Denpasar bulan Agustus sampai Desember 2008. Penelitian ini adalah penelitian quasi experimental dengan rancangan one group pre test dan post test time series design.
Sebagai kelompok kontrol adalah mereka sendiri dengan cara membandingkan nilai-nilai pre test dengan nilai-nilai post test setelah dilakukan intervensi berupa pelatihan hygiene sanitasi makanan dan ditambah pemasangan poster. Penilaian dilakukan 1 kali sebelum pelatihan dan 2 kali setelah pelatihan yaitu bulan pertama dan bulan ke-2 setelah pemasangan poster. Jenis poster ada 4 macam yaitu: 1) poster mencuci tangan dengan benar; 2) poster pemakaian baju kerja; 3) poster cara pencucian alat dengan benar; dan 4) poster syarat penyimpanan bahan makanan dan makanan jadi.

Tujuan penelitian ini adalah untuk mengetahui pengaruh pelatihan hygiene sanitasi dan pemasangan poster terhadap pengetahuan, perilaku sehat penjamah makanan, dan kelaikan hygiene sanitasi.

Subjek adalah penjamah makanan yang bertugas di ruang pengolahan dan ruang rawat inap. Jumlah subjek yang diteliti sebanyak 44 orang yang bekerja di bagian persiapan, pengolahan, dan petugas di ruang rawat inap. Kriteria inklusi sampel yaitu: pendidikan SMU/ sederajat, bertugas di ruang persiapan, pengolahan dan distribusi, bertugas rutin di dapur ruang rawat inap pasien kelas I, II, III dewasa.

Variabel bebas penelitian ini berupa pelatihan hygiene sanitasi dan pemasangan poster, variabel terikat meliputi pengetahuan, perilaku, kualitas keamanan makanan dan kelaikan hygiene sanitasi, serta variabel bebas lainnya terdiri dari umur, jenis kelamin, status perkawinan, masa kerja, dan tempat tugas.

Pelatihan hygiene sanitasi makanan dilakukan pada bulan September 2008. Metode pelatihan dengan metode ceramah, diskusi, dan demontrasi dengan alat bantu audiovisual. Materi pelatihan hygiene sanitasi makanan diadopsi dari kurikulum kursus hygiene sanitasi makanan bagi penjamah makanan berdasarkan Kepmenkes Nomor 715/ Menkes/SK/V/2003 tentang persyaratan hygiene sanitasi jasaboga (9). Pemasangan poster dilakukan setelah pengamatan bulan pertama sesudah pelatihan.

Jenis data yang dikumpulkan yaitu jenis kelamin, umur, status perkawinan, lama bekerja, dan tempat tugas. Data pengetahuan dengan bantuan kuesioner dalam bentuk pilihan ganda dengan memilih salah satu jawaban yang benar. Nilai pengetahuan merupakan perhitungan dari jumlah jawaban yang benar dibagi jumlah seluruh soal, kemudian dikalikan $100 \%$. Observasi perilaku penjamah makanan dibantu oleh enumerator dengan menggunakan daftar tilik berdasarkan pedoman hygiene personal Depkes. Nilai hasil observasi perilaku penjamah makanan adalah jumlah seluruh aspek yang dilakukan dibagi jumlah nilai maksimal kegiatan yang harus dilakukan dengan benar, kemudian dikalikan 100\%. Untuk mengetahui hubungan pengetahuan dengan perilaku dikategorikan menjadi pengetahuan baik dan pengetahuan kurang, perilaku baik dan perilaku kurang. 
Sampel penelitian sebanyak 8 sampel makanan yaitu makanan pasien dewasa yang sudah disajikan pada alat makan pasien kelas I, II dan III meliputi menu pagi hari sebanyak 3 sampel yaitu telur bumbu lengkap, tahu bumbu merah, dan sonde. Menu siang hari sebanyak 5 sampel yaitu daging giling bumbu rendang, ikan bumbu kuning, buah pepaya, sayur urap, dan bubur kacang hijau, diambil di ruang rawat inap kelas III.

Kelaikan hygiene sanitasi adalah penilaian kelaikan hygiene sanitasi instalasi gizi berdasarkan pedoman pemeriksaan kelaikan hygiene sanitasi rumah makan dan restoran nomor: 1098/Menkes/SK/VII/2003.

Analisis untuk mengetahui pengaruh pelatihan terhadap nilai pengetahuan, nilai perilaku, kualitas keamanan makanan dilakukan dengan uji statistik paired sample t-test dengan taraf kemaknaan sebesar 0,05. Untuk mengetahui hubungan karakteristik subjek dengan pengetahuan dan perilaku menggunakan uji statistik Kai Kuadrat.

\section{HASIL}

\section{Karakteristik subjek}

Jumlah subjek pada penelitian ini sebanyak 44 orang dengan latar belakang pendidikan SMU atau sederajat. Selengkapnya karakteristik dan jumlah subjek terdapat pada Tabel 1.

\section{Pengetahuan}

Rerata nilai pengetahuan subjek sebelum dilakukan pelatihan adalah $71,00 \pm 14,12$ dan satu bulan setelah pelatihan meningkat menjadi $80,50 \pm 13,14$ dengan peningkatan sebanyak $9,47 \pm 13,10$. Hasil uji paired sample t test diperoleh nilai p sebesar $0,000(p<0,05)$. Hal ini berarti ada perbedaan bermakna pengetahuan subjek sebelum pelatihan dengan 1 bulan setelah pelatihan.

Penilaian 2 bulan setelah pelatihan ditambah pemasangan poster menjadi $80,80 \pm 14,63$. Peningkatan nilai pengetahuan sebelum dan bulan ke-2 setelah pelatihan ditambah poster sebanyak $9,75 \pm 14,23$, dan bulan pertama dengan bulan ke-2 setelah pelatihan ditambah poster meningkat hanya $0,28 \pm 8,35$. Berdasarkan hasil uji statistik, nilai sebelum dan bulan ke-2 setelah pelatihan ditambah poster menunjukkan hubungan bermakna
TABEL 1. Karakteristik penjamah makanan

\begin{tabular}{ccc}
\hline Karakteristik & $\begin{array}{c}\text { Jumlah } \\
\text { (n total } \mathbf{4 4} \text { ) }\end{array}$ & Persentase (\%) \\
\hline Umur (tahun) & & \\
$\leq 25$ & 10 & 22,7 \\
$26-30$ & 3 & 6,8 \\
$31-35$ & 10 & 22,7 \\
$36-40$ & 11 & 25,0 \\
$41-45$ & 6 & 13,6 \\
$\geq 46$ & 4 & 9,1 \\
Jenis kelamin & & \\
Laki-laki & 8 & 18,2 \\
Perempuan & 36 & 81,8 \\
Status perkawinan & & \\
Kawin & 35 & 79,5 \\
Belum kawin & 11 & 25,0 \\
Masa kerja (tahun) & & \\
$<5$ & 15 & 34,1 \\
5 - 10 & 7 & 15,9 \\
$11-15$ & 13 & 29,5 \\
16 - 20 & 5 & 11,4 \\
$\geq 21$ & 4 & 9,1 \\
Tempat tugas & 21 & 52,3 \\
Pengolahan & 23 & \\
Rawat inap & & \\
\hline
\end{tabular}

dengan nilai $p$ sebesar $0,000(p<0,05)$. Sedangkan bulan pertama dan bulan ke-2 setelah pelatihan ditambah poster tidak menunjukkan hubungan bermakna $(p=0,822)$. Hasil uji statistik disajikan pada Tabel 2.

Tabel 3 menunjukkan bahwa tidak ada hubungan bermakna antara umur, jenis kelamin, status perkawinan, lamanya bekerja, dan tempat tugas subjek, baik terhadap nilai pengetahuan sebelum pelatihan dan 1 bulan setelah pelatihan maupun 2 bulan setelah pelatihan ditambah poster.

\section{Perilaku}

Hasil pengamatan nilai perilaku subjek menggunakan daftar tilik meliputi 17 kegiatan. Rerata nilai perilaku subjek pada pengamatan sebelum pelatihan adalah sebesar $43,72 \pm 11,45$, namun pada saat 1 bulan setelah pelatihan meningkat menjadi $56,55 \pm 16,16$. Peningkatan nilai perilaku pengamatan sebelum dengan 1 bulan setelah pelatihan sebesar $12,83 \pm 18,18$. Hasil uji statistik sebelum dan bulan ke-

TABEL 2. Hasil uji paired sample t test pengetahuan subjek

\begin{tabular}{ccccccc}
\hline \multicolumn{1}{c}{ Aspek } & Selisih & $\begin{array}{c}\text { Standar } \\
\text { deviasi }\end{array}$ & $\mathbf{t}$ & df & Sig. & Keterangan \\
\hline Sebelum - 1 bulan sesudah pelatihan & 9,47 & 13,096 & $-4,794$ & 43 & 0,000 & Meningkat \\
$\begin{array}{c}\text { Sebelum - 2 bulan sesudah pelatihan } \\
\text { ditambah poster }\end{array}$ & 9,75 & 14,234 & $-4,543$ & 43 & 0,000 & Meningkat \\
$\begin{array}{c}1 \text { bulan - 2 bulan sesudah pelatihan } \\
\text { ditambah poster }\end{array}$ & 0,28 & 8,353 & $-0,226$ & 43 & 0,822 & Meningkat \\
\hline
\end{tabular}


1 sesudah pelatihan menunjukkan adanya perbedaan yang sangat bermakna dengan nilai p sebesar $0,000(<0,05)$.

Rerata perilaku bulan ke-2 setelah pelatihan ditambah poster menjadi $66,85 \pm 10,47$. Peningkatan nilai perilaku sebelum dengan bulan ke-2 sesudah pelatihan nilai menjadi $23,13 \pm 15,08$, dan nilai pengamatan bulan ke-1 dan ke-2 setelah pelatihan ditambah poster yaitu 10,29 $\pm 15,12$. Hasil uji statistik sebelum dan bulan ke-2, dan antara bulan

\section{Hubungan pengetahuan dan perilaku}

Berdasarkan hasil uji Kai Kuadrat pada Tabel 6 menunjukkan bahwa nilai pengetahuan dengan nilai perilaku sebelum 1 bulan, sesudah pelatihan, dan 2 bulan sesudah pelatihan ditambah poster tidak mempunyai hubungan bermakna dengan nilai $p>0,05$.

TABEL 3. Hasil uji kai kuadrat $\left(\chi^{2}\right)$ antara karakteristik subjek dengan nilai pengetahuan

\begin{tabular}{lccc}
\hline \multicolumn{1}{c}{ Aspek yang diuji } & $\begin{array}{c}\text { Nilai } \mathbf{p} \\
\text { sebelum pelatihan }\end{array}$ & $\begin{array}{c}\text { Nilai } \mathbf{p} \\
\text { sesudah pelatihan } \\
\text { bulan ke-1 }\end{array}$ & $\begin{array}{c}\text { Nilai } \mathbf{p} \\
\text { sesudah pelatihan ditambah poster } \\
\text { bulan ke-2 }\end{array}$ \\
\hline Umur -pengetahuan & 0,145 & 0,120 & 0,659 \\
Jenis kelamin- pengetahuan & 0,068 & 0,970 & 0,120 \\
Status perkawinan - & 0,238 & 0,439 & 0,696 \\
$\quad$ pengetahuan & 0,236 & 0,546 & 0,251 \\
Lama bekerja- pengetahuan & 0,099 & 0,614 & 0,148 \\
Tempat tugas- pengetahuan & & & \\
\hline
\end{tabular}

TABEL 4. Hasil uji paired sample t test nilai perilaku subjek

\begin{tabular}{|c|c|c|c|c|c|c|}
\hline Aspek & Selisih & $\begin{array}{l}\text { Standar } \\
\text { deviasi }\end{array}$ & $\mathbf{t}$ & df & Sig. & Keterangan \\
\hline $\begin{array}{l}\text { Sebelum - } 1 \text { bulan sesudah } \\
\text { pelatihan }\end{array}$ & 12,8345 & 18,1760 & $-4,684$ & 43 & 0,000 & Meningkat \\
\hline $\begin{array}{l}\text { Sebelum - } 2 \text { bulan sesudah } \\
\text { pelatihan ditambah poster }\end{array}$ & 23,1291 & 15,0847 & $-10,171$ & 43 & 0,000 & Meningkat \\
\hline $\begin{array}{l}1 \text { bulan - } 2 \text { bulan sesudah } \\
\text { pelatihan ditambah poster }\end{array}$ & 10,2945 & 15,1228 & $-4,515$ & 43 & 0,000 & Meningkat \\
\hline
\end{tabular}

pertama dan ke-2 sesudah pelatihan ditambah poster menunjukkan adanya perbedaan yang sangat bermakna dengan nilai $p$ sebesar 0,000 $(<0,05)$. Hasil uji statistik perilaku selengkapnya terdapat pada Tabel 4.

Berdasarkan hasil uji Kai Kuadrat antara karakteristik dengan nilai perilaku subjek setelah dilakukan pelatihan menunjukkan adanya hubungan bermakna menurut jenis kelamin $(p=0,045)$ yaitu pada pengamatan sebelum pelatihan dan 1 bulan sesudah pelatihan. Sedangkan menurut tempat tugas mempunyai hubungan bermakna pada pengamatan bulan pertama setelah pelatihan $(p=$ 0,021).

Setelah dilakukan pemasangan poster pada pengamatan bulan ke-2, tidak ada yang mempunyai hubungan bermakna. Hasil uji statistik selengkapnya terdapat pada Tabel 5.

\section{Kualitas keamanan makanan}

Hasil pemeriksaan mikrobiologis meliputi angka kuman, E.coli Staphylococcus aureus dan Salmonella. Pada Gambar 1 disajikan hasil pemeriksaan mikrobiologis terhadap 8 sampel makanan yang tidak memenuhi syarat pada pemeriksaan sebelum, 1 bulan, dan 2 bulan setelah pelatihan ditambah poster.

Berdasarkan uji paired sample t test diperoleh bahwa pemeriksaan angka kuman sebelum dan satu bulan sesudah pelatihan tidak ada perbedaan yang bermakna. Sedangkan hasil pemeriksaan angka kuman antara 1 bulan setelah pelatihan dan 2 bulan sesudah pelatihan ditambah poster mempunyai hubungan bermakna sangat lemah $(p=0,049)$. Adapun hasil pemeriksaan kuman patogen E.coli tidak ada yang menunjukkan hubungan bermakna (Tabel 7).

TABEL 5. Hasil uji kai kuadrat $\left(\chi^{2}\right)$ antara karakteristik dengan nilai perilaku subjek

\begin{tabular}{lccc}
\hline \multicolumn{1}{c}{ Aspek yang diuji } & $\begin{array}{c}\text { Nilai } \mathbf{p} \\
\text { sebelum } \\
\text { pelatihan }\end{array}$ & $\begin{array}{c}\text { Nilai } \mathbf{p} \\
\text { sesudah pelatihan } \\
\mathbf{1} \text { bulan }\end{array}$ & $\begin{array}{c}\text { Nilai } \mathbf{p} \\
\text { sesudah pelatihan ditambah poster } \\
\text { 2 bulan }\end{array}$ \\
\hline Umur - Perilaku & 0,364 & 0,312 & 0,638 \\
Jenis kelamin - Perilaku & 0,045 & 0,000 & 0,289 \\
Status perkawinan - Perilaku & 0,749 & 0,386 & 0,645 \\
Lama bekerja - Perilaku & 0,909 & 0,181 & 0,337 \\
Tempat tugas - Perilaku & 0,581 & 0,021 & 0,775 \\
\hline
\end{tabular}


TABEL 6. Persentase nilai pengetahuan dengan nilai perilaku hygiene subjek menurut kategori baik dan kurang baik

\begin{tabular}{|c|c|c|c|c|c|c|}
\hline \multirow{2}{*}{ Pengetahuan } & \multicolumn{2}{|c|}{ Sebelum pelatihan } & \multicolumn{2}{|c|}{$\begin{array}{l}\text { Sesudah pelatihan } \\
\text { bulan ke-1 }\end{array}$} & \multicolumn{2}{|c|}{$\begin{array}{l}\text { Sesudah pelatihan ditambah poster } \\
\text { bulan ke-2 }\end{array}$} \\
\hline & $\begin{array}{l}\text { Perilaku } \\
\text { baik }\end{array}$ & $\begin{array}{l}\text { Perilaku } \\
\text { kurang }\end{array}$ & $\begin{array}{l}\text { Perilaku } \\
\text { baik }\end{array}$ & $\begin{array}{l}\text { Perilaku } \\
\text { kurang }\end{array}$ & $\begin{array}{l}\text { Perilaku } \\
\text { baik }\end{array}$ & $\begin{array}{l}\text { Perilaku } \\
\text { kurang }\end{array}$ \\
\hline Pengetahuan baik & $\begin{array}{c}3 \\
(6,8 \%)\end{array}$ & $\begin{array}{c}26 \\
(59,1 \%)\end{array}$ & $\begin{array}{c}22 \\
(50 \%)\end{array}$ & $\begin{array}{c}13 \\
(29,5 \%)\end{array}$ & $\begin{array}{c}29 \\
(65,9 \%)\end{array}$ & $\begin{array}{c}5 \\
(11,4 \%)\end{array}$ \\
\hline Pengetahuan kurang & $\begin{array}{c}4 \\
(9,1 \%)\end{array}$ & $\begin{array}{c}11 \\
(25 \%)\end{array}$ & $\begin{array}{c}2 \\
(2 \%)\end{array}$ & $\begin{array}{c}7 \\
(15,9 \%)\end{array}$ & $\begin{array}{c}6 \\
(13,6 \%)\end{array}$ & $\begin{array}{c}4 \\
(9,1 \%)\end{array}$ \\
\hline Jumlah & $\begin{array}{c}7 \\
(15,9 \%\end{array}$ & $\begin{array}{c}37 \\
(84,1 \%)\end{array}$ & $\begin{array}{c}24 \\
(54,5 \%)\end{array}$ & $\begin{array}{c}20 \\
(45,5 \%)\end{array}$ & $\begin{array}{c}35 \\
(79,5 \%)\end{array}$ & $\begin{array}{c}9 \\
(20,5 \%)\end{array}$ \\
\hline Nilai $p$ & \multicolumn{2}{|c|}{0,207} & \multicolumn{2}{|c|}{0,057} & \multicolumn{2}{|c|}{0,175} \\
\hline
\end{tabular}

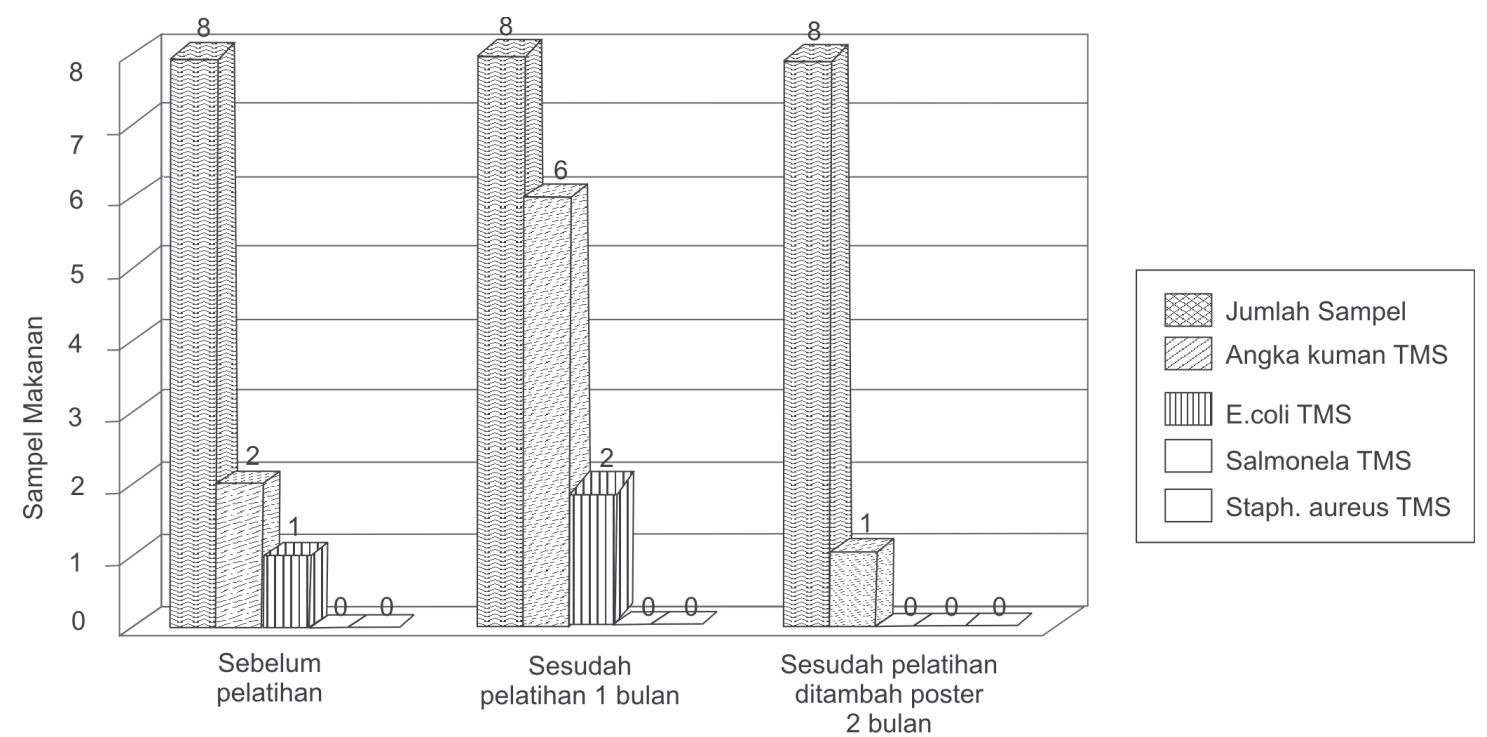

GAMBAR 1. Hasil pemeriksaan mikrobiologis yang tidak memenuhi syarat kesehatan

\section{Penilaian kelaikan hygiene sanitasi}

Hasil penilaian kelaikan hygiene sanitasi dari sebelum pelatihan dengan skor $481(<700)$ tidak memenuhi syarat kelaikan hygiene sanitasi dan 2 bulan setelah pelatihan ditambah poster mengalami peningkatan 283,5 menjadi 764,5 (>700) memenuhi kelaikan hygiene sanitasi. Selengkapnya peningkatan skor kelaikan hygiene sanitasi dapat dilihat pada Tabel 8.

\section{BAHASAN}

Rumah sakit khususnya rumah sakit pemerintah adalah menjadi tujuan utama bagi semua masyarakat yang memerlukan perawatan dengan harapan mendapat pelayanan medis yang lebih baik, lengkap, cepat, dan terjaganya keamanan dari risiko infeksi nosokomial dari semua layanan kesehatan yang terkait, termasuk pelayanan gizi.

TABEL 7. Hasil uji paired sampel $t$ test pemeriksaan angka kuman dan $E$. coli

\begin{tabular}{|c|c|c|c|c|c|}
\hline Jenis mikrobiologi & Mean & $\begin{array}{l}\text { Standar } \\
\text { deviasi }\end{array}$ & $\mathbf{t}$ & df & Sig. \\
\hline \multicolumn{6}{|l|}{ Angka kuman } \\
\hline Sebelum - 1 bulan sesudah pelatihan & $-0,500$ & 0,756 & $-1,871$ & 7 & 0,104 \\
\hline Sebelum - 2 bulan pelatihan ditambah poster & 0,125 & 0,354 & 1,000 & 7 & 0,351 \\
\hline 1 bulan - 2 bulan sesudah pelatihan ditambah poster & 0,625 & 0,744 & 2,376 & 7 & 0,049 \\
\hline \multicolumn{6}{|l|}{ E.Coli } \\
\hline Sebelum - 1 bulan sesudah pelatihan & $-0,125$ & 0,354 & $-1,000$ & 7 & 0,351 \\
\hline Sebelum - 2 bulan sesudah pelatihan ditambah poster & 0,125 & 0,354 & 1,000 & 7 & 0,351 \\
\hline 1 bulan - 2 bulan sesudah pelatihan ditambah poster & 0,250 & 0,463 & 1,528 & 7 & 0,170 \\
\hline
\end{tabular}




\section{Pengetahuan}

Tabel 2 menunjukkan bahwa hasil rerata peningkatan nilai pengetahuan sebelum dan 1 bulan sesudah pelatihan dengan nilai 9,47. Hasil uji statistik menunjukkan adanya hubungan bermakna antara nilai pengetahuan subjek sebelum pelatihan dengan 1 bulan setelah pelatihan $(p<, 001)$. Hal ini sesuai dengan penelitian di Instalasi Gizi menurun, banyaknya informasi lain, dan aturan-aturan yang harus ditaati dalam menjalankan tugas. Alasan utama kegagalan mengingat semakin sering terjadi disebabkan interferensi sehingga isyarat pengambilan pengetahuan baru yang relevan menjadi semakin overload bersama berjalannya waktu (12).

Pemasangan poster sesudah penilaian bulan pertama tidak memberikan pengaruh terhadap nilai

TABEL 8 Skor penilaian kelaikan hygiene sanitasi sebelum dan 2 bulan setelah pelatihan ditambah poster

\begin{tabular}{|c|c|c|c|c|}
\hline \multirow[t]{2}{*}{ Variabel hygiene sanitasi } & \multirow{2}{*}{$\begin{array}{l}\text { Skor } \\
\text { standar }\end{array}$} & $\begin{array}{l}\text { Sebelum } \\
\text { pelatihan }\end{array}$ & $\begin{array}{l}\text { Sesudah pelatihan ditambah poster } \\
2 \text { Bulan }\end{array}$ & Peningkatan \\
\hline & & Skor & Skor & Skor \\
\hline Lokasi dan bangunan & 100 & 72 & 73,5 & 1,5 \\
\hline Fasilitas sanitasi & 150 & 104 & 125 & 21 \\
\hline $\begin{array}{l}\text { Dapur, ruang makan dan } \\
\text { gudang bahan makanan }\end{array}$ & 150 & 40 & 93 & 53 \\
\hline Bahan dan makanan jadi & 110 & 77 & 95 & 18 \\
\hline Pengolahan makanan & 50 & 25 & 40 & 15 \\
\hline $\begin{array}{l}\text { Tempat penyimpanan bahan } \\
\text { makanan dan makanan jadi }\end{array}$ & 90 & 24 & 75 & 51 \\
\hline Penyajian makanan & 50 & 35 & 35 & 0 \\
\hline Peralatan & 150 & 60 & 120 & 60 \\
\hline Tenaga kerja & 150 & 44 & 108 & 64 \\
\hline Total & 1000 & 481 & 764,5 & 283,5 \\
\hline
\end{tabular}

RS Jantung Harapan Kita Jakarta yang menunjukkan bahwa terjadi peningkatan hasil skor pengetahuan sebelum dan 1 bulan sesudah pelatihan keamanan pangan (7). Begitu pula dengan penelitian di Tapanuli Utara yang menyatakan bahwa memberikan pendidikan kesehatan reproduksi melalui media ceramah dan ceramah plus audiovisual menunjukkan hasil yang sangat bermakna terhadap pengetahuan kesehatan reproduksi pada remaja, tetapi metode ceramah plus audiovisual memberikan hasil yang lebih baik (9). Pancaindera menentukan berapa banyak informasi yang diserap jika melibatkan mata, telinga disertai diskusi, latihan dan penggunaan, maka informasi akan terserap $90 \%$ (10).

Peningkatan nilai pengetahuan sebelum pelatihan dan bulan ke-2 setelah pelatihan ditambah poster dengan nilai 9,75 , sedangkan antara bulan pertama setelah pelatihan dan bulan ke-2 sesudah pelatihan ditambah poster meningkat hanya 0,2. Hasil uji sebelum dan 2 bulan sesudah pelatihan ditambah poster menunjukkan hubungan bermakna $(p<0,001)$, sedangkan hasil uji statistik penilaian bulan pertama setelah pelatihan atau sebelum ditambah poster dengan bulan ke-2 setelah pelatihan ditambah poster tidak menunjukkan perbedaan bermakna $(p=0,822)$.

Hal itu sesuai dengan penelitian di Purworejo bahwa poster tidak efektif terhadap peningkatan pengetahuan keluarga tentang kehamilan risiko tinggi dan tanda-tanda bahaya (11). Adanya peningkatan yang tidak bermakna dalam jangka waktu tertentu dapat disebabkan daya ingat pengetahuan, hal ini kemungkinan dapat disebabkan kurangnya motivasi, minat membaca, dan perhatian subjek karena tuntutan pekerjaan yang cepat dan tepat waktu dalam penyediaan makanan. Selain itu kemungkinan pesan atau desain poster kurang menarik, bahasanya kurang dimengerti dan ukuran kurang tepat. Seharusnya sebelum membuat desain sebuah poster harus dilakukan tes pendahuluan (13). Sedangkan pada penelitian ini tidak dilakukan tes pendahuluan, poster langsung dipasang di tempat penjamah makanan melakukan aktivitas.

Aspek pengetahuan yang masih kurang seperti bahan pencemaran makanan yang terkait dengan menyebutkan jenis kuman patogen yang memakai nama ilmiah seperti E.coli dan Staphylococcus, pengetahuan yang kurang juga terkait dengan pencucian peralatan dan menyebutkan jenis desinfektan yang dipergunakan untuk mencuci peralatan. Kemungkinan pelatihan yang terkait prosedur kerja dan jenis-jenis bahan yang dipergunakan, akan lebih efektif bila dilakukan langsung di tempat kerja.

Berdasarkan Tabel 3 hubungan karakteristik dengan nilai pengetahuan, sebelum dan bulan pertama setelah pelatihan tidak mempunyai hubungan bermakna. Pada bulan ke-2 setelah pelatihan ditambah poster juga tidak mempunyai perbedaan bermakna $(p>0,05)$. Hal ini menunjukkan bahwa adanya poster yang berisi pesan dan pemberitahuan higiene sanitasi tidak efektif meningkatkan pengetahuan dari masing-masing karakteristik subjek. 


\section{Perilaku}

Pelatihan juga ditujukan agar terjadi perubahan sikap dan perilaku yang positif untuk menanamkan kebiasaan baru. Pada Tabel $\mathbf{4}$ ditunjukkan bahwa kegiatan pelatihan dapat meningkatkan nilai perilaku subjek sebelum dan sesudah pelatihan yaitu sebesar 12,83 . Berdasarkan hasil uji paired sample $t$ test menunjukkan hubungan secara bermakna $(p<0,001)$. Perilaku penjamah makanan setelah diberikan pelatihan sanitasi makanan secara klasikal juga terjadi peningkatan (14).

Hasil observasi perilaku sebelum pelatihan dan bulan ke-2 sesudah pelatihan ditambah poster juga terjadi peningkatan dengan nilai 23,13 . Penilaian bulan ke-2 setelah pelatihan ditambah poster, terjadi peningkatan nilai sebanyak 10,29. Berdasarkan hasil uji statistik sebelum pelatihan dengan bulan ke-2 setelah pelatihan, dan antara bulan pertama dengan bulan ke-2 setelah pelatihan ditambah poster menunjukkan perbedaan secara bermakna $(p<0,001)$. Melakukan penyuluhan dengan menggunakan media buku saku dan poster dapat meningkatkan hygiene perorangan dan perilaku dalam hal sanitasi pengolahan makanan (15). Pemasangan poster mungkin juga dapat disebabkan karena penambahan tempat cuci tangan lengkap dengan tempat sabun di ruang pendistribusian dan ruang makan pegawai.

Perilaku sehat yang masih kurang dilakukan yaitu mencuci tangan dengan sabun seperti sebelum bekerja, setelah memegang bahan kotor atau bahan mentah, setelah memegang anggota tubuh rata-rata sebanyak $28 \%$, dan tidak bercakap-cakap sambil bekerja sebanyak $29,5 \%$.

Setelah dilakukan pemasangan poster di tempat kerja walaupun terjadi hubungan bermakna antara 1 bulan dengan 2 bulan setelah pelatihan ditambah poster, juga terjadi penurunan yaitu mencuci tangan dengan sabun setelah memegang anggota tubuh sebanyak $20,5 \%$. Faktor-faktor ini sangat memungkinkan terjadinya kontaminasi mikroorganisme pada makanan yang disajikan kepada pasien. Menurut penelitian di Yogyakarta tahun 2005, perubahan sikap dan perilaku diperlukan waktu yang relatif lama dan diulang-ulang sehingga memperbesar kesempatan untuk berperilaku lebih baik dan bahwa pengetahuan yang bagus tidak selamanya dapat diekspresikan dalam sikap dan perilaku yang baik pula (16). Pengetahuan, keterampilan dan sikap sebagai penjamah makanan yang dimiliki dan dilaksanakan bertahun-tahun dapat mempengaruhi perubahan perilaku atau kebiasaan baru yang cukup lama, karena makanan yang diberikan selama ini tidak menimbulkan keluhan atau masalah yang dapat memperberat penyakit pasien itu sendiri. Hal ini juga dapat disebabkan karena belum pernah adanya keluhan langsung dari pasien dan kejadian tidak diinginkan yang disebabkan oleh makanan yang terkontaminasi oleh mikroorganisme.
Tabel 5 menunjukkan bahwa antara karakteristik dengan perilaku menghasilkan hubungan secara bermakna yaitu antara jenis kelamin dan perilaku sebelum pelatihan $(p=0,045)$ dan sesudah satu bulan pelatihan $(p<0,001)$. Jenis kelamin yang mengalami peningkatan nilai perilaku tertinggi yaitu laki-laki. Dilihat dari hasil pengamatan perilaku penjamah laki-laki yang paling menonjol adalah tidak bercakap-cakap atau berbicara sambil bekerja, tidak berkuku panjang, tidak merokok/ memakai perhiasan. Hal ini berbeda dengan penelitian di Rumah Sakit Sicily Italia yang menunjukkan bahwa terdapat hubungan bermakna antara praktik menjaga keamanan makanan dengan perilaku mencuci tangan pada wanita sebelum dan sesudah memegang bahan/makanan (17).

Hasil pengamatan pada bulan pertama setelah pelatihan menurut tempat tugas mempunyai perbedaan secara bermakna dengan nilai $p$ sebesar 0,021 . Tempat tugas yang mengalami peningkatan nilai perilaku yaitu unit pengolahan makanan. Begitu pula hasil penelitian di Instalasi Gizi Rumah Sakit Jantung Harapan Kita Jakarta menunjukkan bahwa tempat tugas dengan skor kebersihan diri juga mempunyai hubungan bermakna (7). Peningkatan perilaku di ruang pengolahan dapat disebabkan karena kelengkapan fasilitas di unit pengolahan lebih banyak seperti kelengkapan baju kerja, celemek dan tutup kepala.

Perubahan perilaku berdasarkan karakteristik setelah dilakukan penambahan poster hygiene sanitasi pada bulan ke-2 setelah pelatihan tidak mempunyai hubungan bermakna $(p>0,05)$.

\section{Hubungan pengetahuan dengan perilaku}

Pengetahuan yang baik akan memberikan pengaruh perilaku yang baik pula. Pada Tabel 6 dijelaskan penilaian pengetahuan dan perilaku menurut baik dan kurang baik. Penilaian sebelum pelatihan menurut pengetahuan baik dan perilaku baik hanya 3 orang $(6,8 \%)$, satu bulan setelah pelatihan menunjukkan peningkatan pengetahuan baik dan perilaku baik menjadi 22 orang (50\%). Berdasarkan hasil uji Kai Kuadrat menunjukkan bahwa nilai pengetahuan dengan nilai perilaku sebelum dan sesudah pelatihan tidak mempunyai hubungan bermakna $(p>0,05)$.

Setelah dilakukan pemasangan poster pada bulan ke-2 setelah pelatihan, terjadi peningkatan pengetahuan dan perilaku dengan kategori baik yaitu 29 orang $(65,9 \%)$. Tetapi dari hasil uji statistik bulan ke-2 setelah pelatihan ditambah poster menunjukkan tidak mempunyai hubungan bermakna $(0,175)$. Pengetahuan mengenai sanitasi pengelolaan makanan tidak memberikan pengaruh terhadap perilaku dalam melakukan pengelolaan makanan (17). Pengetahuan bukan sebagai faktor utama dalam perubahan perilaku, tetapi perilaku yang didasari oleh pengetahuan dan kesadaran hygiene sanitasi lebih langgeng daripada tidak didasari pengetahuan (13). 


\section{Kualitas keamanan makanan}

Keamanan makanan sangat dipengaruhi oleh perilaku semua staf yang terkait dengan pelayanan makanan khususnya makanan di rumah sakit. Kontaminasi kuman lebih banyak oleh penjamah makanan karena berhubungan langsung dengan makanan, dan diikuti penyebaran lebih luas dari orang ke-orang di lingkungan rumah sakit (18).

Berdasarkan Gambar 1 dan Tabel 7 hasil pemeriksaan sebelum pelatihan, sampel makanan yang tidak memenuhi syarat atau mengandung angka kuman sebanyak 2 sampel, mengandung E.coli terdapat pada 1 sampel yaitu menu pagi tahu bumbu merah. Hasil pemeriksaan bulan pertama setelah pelatihan terdapat angka kuman pada 6 sampel makanan yaitu semuanya terdapat pada menu makan siang, dan E.coli terdapat pada 2 sampel makanan, yaitu pada tahu bumbu merah dan bubur kacang hijau. Hasil pemeriksaan Staphylococcus dan Salmonella tidak terdapat pada semua sampel makanan. Berdasarkan hasil uji statistik angka kuman dan $E$. coli sebelum dengan bulan pertama setelah pelatihan menunjukkan tidak ada hubungan bermakna $(p>0,05)$. Banyaknya makanan yang mengandung angka kuman dan E.coli menandakan bahwa pada makanan terkontaminasi oleh kotoran manusia yang disebabkan sanitasi yang kurang baik dan hygiene personal yang kurang sehat. Makanan yang mengandung kuman sebagai sumber infeksi nosokomial bagi pasien, di mana pasien yang dirawat di rumah sakit mempunyai sistem imun yang lemah akibat penyakit/ cedera, faktor stres, sehingga mempermudah pertumbuhan kuman patogen dan menyebabkan sakit lebih berat (4).

Pemeriksaan angka kuman pada bulan ke-2 setelah pelatihan ditambah poster terjadi penurunan angka kuman yaitu terdapat pada satu sampel makanan. Berdasarkan hasil uji statistik kandungan angka kuman bulan pertama dan bulan ke-2 setelah pelatihan ditambah poster menunjukkan perbedaan bermakna dengan nilai p: 0,049. Sedangkan hasil uji statistik kandungan E.coli tidak mempunyai hubungan bermakna $(p>0,05)$, tetapi dari segi kualitas makanan mengalami peningkatan, begitu pula menurut hasil penelitian di RSUD Kota Banjar bahwa pelatihan hygiene sanitasi pengolahan makanan dapat meningkatkan kualitas makanan secara mikrobiologis (19).

Tingginya angka kuman pada bulan pertama setelah pelatihan dapat disebabkan karena perilaku sehat masih rendah, seperti kebiasaan mencuci tangan dengan sabun, hal ini dapat disebabkan karena kurangnya fasilitas cuci tangan di mana seharusnya 1 tempat cuci tangan untuk 10 orang dan di tempat di masing-masing unit kerja. Mencuci tangan dengan sabun khusus cuci tangan dan dibilas dengan air, menunjukkan hasil berbeda secara bermakna, bahwa mencuci tangan sangat efektif dapat menurunkan kuman E.coli (20). Meningkatkan akses sanitasi dan mencuci tangan dengan sabun juga secara signifikan dapat mengurangi risiko diare (21). Selain hal tersebut di atas, kontaminasi kuman pada makanan dapat disebabkan karena pencucian alat makan yang kurang baik karena kurangnya fasilitas seperti air panas atau desinfektan, adanya renovasi ruang distribusi makanan dapat mencemari makanan baik dari fisik bangunan maupun oleh pekerja bangunan.

\section{Kelaikan hygiene sanitasi}

Hasil penilaian kelaikan hygiene sanitasi pada Tabel 8 sebelum pelatihan dengan skor $481(<700)$ tidak memenuhi kelaikan hygiene sanitasi dan 2 bulan setelah pelatihan ditambah poster mengalami peningkatan 283,5 menjadi 764,5 (>700) memenuhi syarat kelaikan hygiene sanitasi. Berbeda dengan penelitian di Rumah Makan Padang di Kota Yogyakarta mengungkapkan bahwa tidak ada peningkatan fasilitas sanitasi dan kontruksi bangunan rumah makan, disebabkan keterbatasan biaya atau materi dan kurangnya sosialisasi (14).

Peningkatan kelaikan hygiene sanitasi terjadi pada komponen lokasi dan bangunan tidak mengalami perubahan dilihat dari segi fisik, peningkatan hanya terjadi pada dinding di ruang pengolahan dalam keadaan bersih. Sedangkan fasilitas sanitasi mengalami peningkatan yaitu pemisahan toilet laki-laki dan wanita. Pengangkutan sampah tiap 24 jam sudah dilakukan 2 kali sebelumnya hanya diangkut 1 kali pada pagi hari, tetapi setelah pelatihan dilakukan pengeluaran sampah dari ruang pengolahan sebanyak 2 kali pagi dan sore hari. Ada penambahan tempat cuci tangan lengkap dengan tempat sabun, tersedianya desinfektan berupa klorin, sedangkan air panas sudah tersedia cukup lama, namun tidak dimanfaatkan secara maksimal.

Pada komponen dapur, ruang makan dan gudang bahan makanan yang mengalami peningkatan yaitu dapur dalam keadaan bersih, tersedia ruang makan lengkap dengan fasilitas cuci tangan dan terpasang poster pesanpesan hygiene sanitasi bagi penjamah makanan.

Komponen bahan makanan dan makanan menjadi meningkat karena hasil pemeriksaan makanan tidak mengandung kuman patogen dan tidak mengandung zat kimia seperti formalin.

Pada proses pengolahan hanya terjadi peningkatan menggunakan pakaian kerja, celemek, dan tutup kepala yang bersih. Sedangkan pada komponen tempat penyimpanan mengalami peningkatan skor pada cara penyimpanan yaitu persyaratan ketebalan bahan makanan maupun makanan tidak lebih dari $10 \mathrm{~cm}$, penyimpanan sesuai dengan jenis makanan, dan penempatan terpisah dengan makanan jadi. Sudah ada monitoring suhu penyimpanan makanan jadi dan cara penyimpanan dalam keadaan tertutup. Peningkatan pada komponen peralatan yaitu pada cara pencucian dan penyimpanan peralatan agar selalu dalam keadaan bersih. 
Peningkatan pada komponen tenaga kerja yaitu sebagian besar penjamah makanan yang terlibat langsung dengan bahan makanan dan makanan sudah mendapatkan pelatihan hygiene sanitasi dan memiliki sertifikat. Menggunakan pakaian kerja yang bersih, serta adanya peningkatan personal hygiene dari penjamah makanan.

Penilaian kelaikan hygiene sanitasi yang tidak mengalami peningkatan yaitu pada komponen cara penyajian makanan mengenai pengaturan suhu penyajian tidak kurang dari $60^{\circ} \mathrm{C}$. Komponen ini tidak bisa ditindaklanjuti karena kurangnya fasilitas penyimpanan makanan panas dan tidak mempunyai alat pengukuran suhu makanan.

Peningkatan skor kelaikan hygiene sanitasi penyelenggara makanan di rumah sakit, seharusnya dapat memenuhi syarat nilai tertinggi hygiene sanitasi jasaboga. Karena rumah sakit adalah sebagai sarana pelayanan kesehatan yang digolongkan dalam jasa boga golongan $B$. Inspeksi hygiene sanitasi perlu dilakukan secara berkala untuk dapat mengetahui baik tidaknya sanitasi pada penyelenggaraan makanan serta sebagai dasar untuk melakukan pembinaan pada personal, perbaikan, dan melengkapi fasilitas.

\section{KESIMPULAN DAN SARAN}

Berdasarkan hasil penelitian dan analisis maka dapat diambil kesimpulan: 1) Ada peningkatan pengetahuan penjamah makanan sebelum dan setelah pelatihan ditambah poster; 2) Ada peningkatan perilaku sehat penjamah makanan sebelum dan sesudah pelatihan ditambah poster; 3) Ada peningkatan kualitas keamanan makanan bulan pertama dan bulan ke-2 setelah pelatihan ditambah poster; 4) Ada peningkatan kelaikan hygiene sanitasi; dan 5) Ada hubungan bermakna antara jenis kelamin dan perilaku sebelum dan 1 bulan setelah pelatihan, dan tempat tugas dengan perilaku pada bulan pertama setelah pelatihan.

Berdasarkan kesimpulan di atas disarankan agar Rumah Sakit Umum Pusat Sanglah Denpasar dapat memberikan pelatihan/pembinaan hygiene sanitasi secara berkesinambungan dan memperhatikan kebutuhan sarana serta fasilitas hygiene sanitasi. Perlu penelitian lebih lanjut untuk melihat apakah pemasangan poster hygiene sanitasi saja tanpa pelatihan, dapat meningkatkan perilaku sehat pada semua pegawai yang terkait dengan penyelenggaraan makanan dengan waktu observasi yang lebih lama dan disesuaikan dengan shift kerja.

\section{RUJUKAN}

1. Triatmodjo P. Tinjauan mikrobiologi makanan, minuman dan air pada beberapa Rumah Sakit di Jakarta. Jakarta: Cermin Dunia Kedokteran 1993. 37-40.
2. Setiati, Mulyana L, Haryeni D. Studi evaluasi kondisi sanitasi pengelolaan makanan di Instalasi Gizi Dapur Saji Kelas III RSUP DR. Hasan Sadikin Bandung: Jurnal Infomatek 2004; 6(3): 143-54.

3. Badan Pengawasan Obat dan Makanan. Keputusan Kepala BPOM tentang pedoman cara produksi pangan yang baik untuk industri rumah tangga. Jakarta: BPOM; 2003.

4. Widyastuti P. Ed. Penyakit bawaan makanan. Fokus Pendidikan Kesehatan WHO. Jakarta: Buku Kedokteran EGC; 2006.

5. Instalasi Gizi RSUP Sanglah Denpasar. Denpasar: Laporan tahunan; 2007.

6. Fatimah S, Kuntjoro T, Castro T. Pengaruh pelatihan kuliner bagi juru masak terhadap mutu makanan pasien di RSUD Dr. Wahidin Sudirohusodo Makassar. Jurnal Gizi Klinik Indonesia 2007; 4(2): 87-91.

7. Prasetyaningsih A, Sudargo T, Susilo J. Pengetahuan, sikap dan keterampilan penjamah makanan yang diberikan pelatihan keamanan pangan di Instalasi Gizi RS Jantung Harapan Kita. Jurnal Gizi Klinik Indonesia 2005;2(2): 68-74.

8. Departemen Kesehatan RI. Keputusan menteri kesehatan RI tentang persyaratan hygiene sanitasi jasa boga. Jakarta :Depkes RI; 2003.

9. Pandiangan T, Paramastri I, Sayoga B. Pengaruh pendidikan kesehatan reproduksi melalui metode ceramah, media audiovisual, ceramah plus audiovisual pada pengetahuan dan sikap remaja SLTP. Berita Kedokteran Masyarakat 2006; 22(4): 160-5.

10. Bush D, Brow G, Kemp M, O'Rouke D, Szudy B. Pelatihan bagi pelatih kesehatan dan keselamatan kerja. Lembaga Informasi Perburuhan Semarak (alih bahasa). Labor Ocupational Health Program U.C.Barkeley. Universitas of California Berkeley; 2000.

11. Wijayanti GASPW, Hakimi M \& Dewi FST. Efektivitas poster terhadap keluarga tentang kehamilan resiko tinggi dan tanda bahaya kehamilan. Berita Kedokteran Masyarakat 2001;17(3): 113-8.

12. Atkinson RL, Atkinson RC, Smitt EE, Bem DJ. Introduction to Psychology. Kusuma, W. (alih bahasa). Batam : Interaksara; 1993.

13. Notoatmodjo S. Promosi kesehatan dan ilmu perilaku. Jakarta: Rineka Cipta; 2007.

14. Mulyono S. Pengaruh pelatihan sanitasi makanan terhadap peningkatan kualitas mikrobiologis makanan Rumah Makan Padang di Kota Yogyakarta. [Tesis]. Yogyakarta: Pascasarjana Universitas Gadjah Mada; 2001.

15. Musadad DA. Pengembangan media penyuluhan sanitasi pengelolaan makanan bagi pedagang makanan jajanan. Center for Research and Development of Health Ecology, NIHRD [series online] 2003 [cited 2009 March 2]. Available from: http://: www. digilib.itb. 
ac.id.

16. Prabandari YS, Dewi FST, Supriyati, Paramastri I. Pelatihan keterampilan pencegahan perilaku penyalahgunaan narkoba bagi siswa SD dan SMP di Yogyakarta. Berita Kedokteran Masyarakat 2005; 21 : 1-6.

17. Djarismawati, Sukana, Sugiharti. Pengetahuan dan perilaku penjamah tentang sanitasi pengolahan makanan pada Instalasi Gizi Rumah Sakit di Jakarta. Media Litbang Kesehatan 2004;14(3): 31-7.

18. Buccheri C, Casuccio A, Giamnanco S, Giamnanco M, Guardia M, Mammina C. Food safety in hospital: knowledge, attiduts and practices of nursing staff of two hospital in Sicily Italy. BMC Health Services Research
2007; 7:45.

19. Suhendar E. Pelatihan sanitasi pengolahan makanan untuk meningkatkan kinerja penjamah makanan di Rumah Sakit Umum Daerah Kota Banjar. [Tesis]. Yogyakarta: Pascasarjana Universitas Gadjah Mada; 2005.

20. Courtenay M, Ramirez L, Cox B, Han I, Jiang X, Dawson $P$. Effects of various hand hygiene regimes on removal and/or destruction of escherichia coli on hand. USA: Blackwell Publishing. Food Service Technology 2005; 5: 77-84.

21. Anonim. Menkes canangkan gerakan cuci tangan pakai sabun. [serial online] 2006 [cited 2008 April 28]. Available from: http://www.gizi.net. 